\title{
Theorizing a More-than-Human Diplomacy: Assembling the British Foreign Office, 1839-1874
}

\author{
Jason Dittmer \\ Department of Geography, University College London, London WC1E 6BT, \\ United Kingdom \\ j.dittmer@ucl.ac.uk
}

Received: 2 April 2015; revised: 20 June 2015; accepted: 19 July 2015

\section{Summary}

This article emphasizes the more-than-human nature of foreign policy formation and diplomatic practice, as found in an examination of nineteenth-century Parliament Select Committee testimony regarding the intersection of everyday bureaucratic practice and the material context of the British Foreign Office. These records indicate both how the changing world of diplomacy at this time (including new states and communication technologies) materially impacted the Foreign Office, as well as the affective atmosphere experienced by its employees, through an excess of paper. Debates over how the new Foreign Office ought to be built reveal concerns about the circulation of paper, bodies, light and air in a drive for efficiency. These historical materialities speak to our understanding of contemporary changes occurring within the world of diplomacy, including the rise of digital technologies and the new skills needed among diplomats, as well as inform our understanding of the exercise of power within assemblages.

\section{Keywords}

assemblage - materiality - affect - efficiency - paper - parliament

* The author would like to thank audiences at the University of Liverpool, the University of Oxford and at University College London for feedback on earlier versions of this article. Alex Jeffrey and Fiona McConnell were kind enough to read an early draft. All flaws remain my own. This research was funded by the Arts and Humanities Research Council, AH/Koo8110/1.

(C) JASON DITTMER, 2015 | DOI 10.1163/1871191X-12341319 


\section{Introduction}

Mostly enthusiasts of Victorian design know the tale of the Whitehall building that currently houses the British Foreign and Commonwealth Office (FCO), which was completed in $1874 .{ }^{1}$ However, the process of replacing the former office is of interest to scholars of diplomacy, as it enables us to consider the constitution of the foreign ministry as a bureaucracy within a larger diplomatic system, and the role of the non-human in that dispositif or apparatus.

State theorists have in the past identified the 1782 creation of Britain's Foreign Office as a foundational moment for foreign policy as an object of government. ${ }^{2}$ Prior to 1782 , two secretaries of state divided the sovereign's business, not according to a domestic/foreign binary, but rather by a north/south binary that cut across borders: the Northern Department dealt with northern Europe and the northern parts of the realm; while the Southern Department dealt with Ireland, the Americas and the Mediterranean, as well as southern England. In some ways, the pre-1782 arrangement reflected the limited intensity of diplomatic exchange and the aristocratic nature of European diplomacy; it was only in the mid-nineteenth century that the British government considered building a grand dining hall, the London corps diplomatique having finally outgrown the dining facilities available to an average aristocrat/foreign secretary.

In the late eighteenth century, Britain's defeat in the American Revolutionary War contributed to a mood of reorganization, amplified by the material requirements of a rapidly developing administrative apparatus. The Foreign Office, with only nine clerks and three servants, was located in 1782 on Cleveland Row adjacent to St James's Palace, but four years later it was moved to Whitehall Palace, and then seven years after that it transferred to Downing Street. These moves coincided with the "new "total" commitment of the country to the Revolutionary and Napoleonic Wars of 1793-1815, [which] enormously increased the number of staff required to run such large-scale military operations. ${ }^{3}$ There, in improvised accommodation next to the more famous 10 Downing Street, the Foreign Office would remain for decades, part of the nerve

1 Keith Hamilton, 'Accommodating Diplomacy: The Foreign and Commonwealth Office and the Debate over Whitehall Redevelopment', Contemporary British History, vol. 18, no. 3 (2004), pp. 198-222. See also Bernard Porter, The Battle of the Styles: Society, Culture, and the Design of a New Foreign Office, 1855-1861 (London: A\&C Black, 2011).

2 Andrew Vincent, Theories of the State (Oxford: Blackwell, 1987).

3 Anthony Seldon, The Foreign Office: An Illustrated History of the Place and Its People (London: HarperCollins, 2000), p. 39 . 
centre of the British state. These developments might seem mundane, even boring - a series of address changes for a small group of clerks. Alternatively, they indicate how the Foreign Office must be actualized in particular material contexts, which are themselves crucial to the workings of foreign policy formation and the broader project of governmentality.

The empirical objective of this article is to trace the Foreign Office's subsequent improvisation, not only in terms of office space but in a rapidly changing diplomatic system. As the article will demonstrate, the Downing Street Foreign Office was a suitable site at the beginning of its tenure, but changes in the diplomatic system soon highlighted the building's lack of resilience. The lifespan and the affective atmosphere of the building were materially impacted by the rapid growth and intensification of the diplomatic system in which the building was enmeshed. Given the massive expenditure on a new Foreign Office and the length of time it was therefore expected to serve its purpose, it was necessary to extrapolate what the future diplomatic system would look like and how it would work, so that the new building would enable an efficient public service over time.

Conceptually, this article's objective is to address the affective forces that reshape foreign policy apparatuses as a result of their participation in the larger diplomatic system. Processes unfolding elsewhere have effects that ripple through the Foreign Office, and they are borne via the materials of diplomacy. A concern with institutional efficiency and resilience thus emerges during times of rapid change. Nevertheless, because social processes often unfold over different temporalities (for example, the long lifespan of a building versus rapid changes in telecommunications) these attempts to 'future-proof' the institution may have unintended outcomes.

This article proceeds in several parts. First, the literature on the more-thanhuman is reviewed, with an eye towards a theoretical elaboration of diplomacy as the discursive and affective tendons for a global assemblage of state bureaucracies, marked by a relational ontology and uneven intensities of connection among its constituent parts. This review's focus on how non-human elements of the diplomatic apparatus both enable and exceed the traditional anthropocentric remit of diplomatic studies sets up the empirical analysis of the article. After a discussion of methods, the article examines everyday routines of the early- to mid-nineteenth century Foreign Office, with a particular emphasis on the role of paper. Paper is not only the archive that enables transnational governmentality, but is also an unruly element of the diplomatic apparatus, whose materiality posed problems for the Foreign Office, literally shaking it to its foundations. This section speaks to the article's conceptual objectives, by demonstrating the role of materials as vectors for affect within diplomatic 
systems, which can remake foreign policy apparatuses. The article then considers contemporary debates over how to produce affective atmospheres that are conducive to efficient governmentality in the new Foreign Office. This section speaks to the conceptual objectives by emphasizing human efforts to govern the circulation of materials and to design a building that was resilient to changes in the wider diplomatic system. The paper concludes by examining the implications of this scholarship for studies of governmentality, diplomacy and assemblage.

\section{More-than-Human Diplomacy}

Diplomacy has traditionally been considered a human endeavour, which is unsurprising given its usual definition as the practice of diplomats. As an example that is particularly relevant to this study, T.G. Otte's study, The Foreign Office Mind, examined the collective mind-set of those working in the nineteenth-century Foreign Office: their social exclusivity; their public school education; and so on. ${ }^{4}$ Such an approach is useful, but - as the name of Otte's book hints - it emphasizes rationality and human agency. Indeed, the Foreign Office moved into its new building in 1868, but this event is never mentioned, as there is no place for materiality in Otte's account. Otte is, of course, not alone; indeed, the myriad outstanding insights of the 'Practice Turn' within diplomatic studies have re-emphasized the importance of humans. ${ }^{5}$

The role of humans in politics, however, has been decentred by the so-called 'New Materialisms. ${ }^{6}$ This work highlights the role of materials in not only coproducing human agency (for example, as tools), but also in shaping political subjectivities. Hence, these authors argue that we should consider politics to be a more-than-human affair - that is, humans exercising agency are not stable entities, but are themselves shaped by a range of materialities that change over time. ${ }^{7}$ This perspective does not seek to ignore humans and their agency;

4 T.G. Otte, The Foreign Office Mind: The Making of British Foreign Policy, 1865-1914 (Cambridge: Cambridge University Press, 2011).

5 Iver Neumann, At Home with the Diplomats: Inside a European Foreign Ministry (Ithaca, NY: Cornell University Press, 2012); and Merje Kuus, 'Foreign Policy and Ethnography: A Sceptical Intervention', Geopolitics, vol. 18, no. 1 (2012), pp. 115-131.

6 As an example, see Diana Coole and Samantha Frost (eds), New Materialisms: Ontology, Agency, and Politics (Durham, NC: Duke University Press, 2010).

7 Bruce Braun and Sarah Whatmore, Political Matter: Technoscience, Democracy and Public Life (Minneapolis, mN: University of Minnesota Press, 2010); William Connolly, 'The "New Materialism" and the Fragility of Things', Millennium:Journal of International Studies, vol. 41, 
indeed, human agency is special because of humans' ability to be reflexive and intentional. Rather, scholars working within the 'New Materialism' situate human agency within the material context that produced it. As Merje Kuus notes, " $[\mathrm{t}$ ] o study context is not to trace cause in the sense of predicting specific events, but to expose and explicate these events' conditions of possibility'8 From this perspective, the capabilities enabled by the old and new Foreign Office buildings, and other infrastructures of diplomacy, from the telegraph to Twitter, are crucial to the workings of diplomats, and therefore we can begin to speak of a more-than-human diplomacy.

A more-than-human diplomacy is helpfully considered through the lens of assemblage theory. ${ }^{9}$ Andrew Barry has argued that 'instead of drawing a line between the social and technical, one must instead analyse arrangements: of artefacts, practices and techniques, instruments, language and bodies. These arrangements make up what we tend to think of as persons and institutions: states, markets, families, and so on' ${ }^{10}$ These arrangements emerge out of processes such as territorialization (in which the coherence of the assemblage is enhanced) or coding (in which meaning is ascribed to the assemblage). Assemblages are becoming, both because they are open systems into which new elements can enter or from which old elements can leave, and also because elements can participate in multiple assemblages at once, allowing events in one assemblage to affect another. Indeed, elements of an assemblage can also be assemblages themselves, engaged in their own processes of becoming. This troubles the usual scalar imagination of diplomacy and international relations, in which bigger entities are assumed to be more important. Rather, assemblage theory emphasizes non-linear causality, in which small events can

no. 3 (2013), pp. 399-412; Erika Cudworth and Stephen Hobden, Post-human International Relations: Complexity, Ecologism and Global Politics (London: Zed Books, 2011); Jason Dittmer, 'Geopolitical Assemblages and Complexity', Progress in Human Geography, vol. 38, no. 3 (2014), pp. 385-401; Bruno Latour, Reassembling the Social: An Introduction to Actor-Network Theory (Oxford: Oxford University Press, 2005); Tom Lundborg and Nick Vaughn-Williams, 'New Materialisms, Discourse Analysis, and International Relations: A Radical Intertextual Approach', Review of International Studies (early online); and Vicki Squire, 'Reshaping Critical Geopolitics? The Materialist Challenge', Review of International Studies, vol. 41, no. 1 (2015), pp. 139-159.

8 Merje Kuus, 'Bureaucracy and Place: Expertise in the European Quarter', Global Networks, vol. 11, no. 4 (2011), p. 424.

9 Ben Anderson and Colin McFarlane, 'Assemblage and Geography', Area, vol. 43, no. 2 (2011), p. 124.

10 Andrew Barry, Political Machines: Governing a Technological Society (London: Continuum, 2001), p. 11. 
ripple through assemblages, producing macro-scaled effects. Assemblage theory therefore enables us to consider a more-than-human diplomacy as one in which:1) the scalar imagination of international relations is flattened in favour of a relational ontology; and 2) the role of materials in shaping political subjectivity and action is brought to the foreground.

These two insights mean that a more-than-human diplomacy can direct our attention to aspects that have thus far been under-examined. The relatively flat ontology of assemblage emphasizes everyday diplomatic practices and objects in the crafting of the state. ${ }^{11}$ This dovetails with Timothy Mitchell's much-cited description of the state as the tangible effect of everyday bodily performances. ${ }^{12}$ By considering state effects rather than states per $s e e^{13}$ we can both consider a range of diplomatic actors that may not qualify as states and also see the (il)legitimacy of states as the emergent outcome of practices occurring across a range of sites, from the local tax office to the United Nations. ${ }^{14}$ These practices of statecraft are open-ended and often improvised, as actors seek to promote their own state visions..$^{15}$ However, the second point above - about the role of materials in political life - means that diplomatic practices entail the coming together of the human and non-human in particular ways, which in the best of circumstances requires work and often fails to occur. This is evident in, for example, the importance of gifts to diplomatic encounters. ${ }^{16}$ Iver Neumann's account of the diplomatic party is a case in point: preparation for

11 For example, Alex Jeffrey and Michaelina Jakala, 'The Hybrid Legal Geographies of a War Crimes Court', Annals of the Association of American Geographers, vol. 104, no. 3 (2014), pp. $65^{2-667 .}$

12 Timothy Mitchell, 'The Limits of the State: Beyond Statist Approaches and their Critics', American Political Science Review, vol. 85, no. 1 (1991), pp. 77-96.

13 Joe Painter, 'Prosaic Geographies of Stateness', Political Geography, vol. 25, no. 7 (2006), pp. $75^{2-774 .}$

14 Fiona McConnell, 'De Facto, Displaced, Tacit: The Sovereign Articulations of the Tibetan Government-in-Exile', Political Geography, vol. 28, no. 6 (2009), pp. 343-352; and Fiona McConnell, Terri Moreau and Jason Dittmer, 'Mimicking State Diplomacy: The Legitimizing Strategies of Unofficial Diplomacies', Geoforum, vol. 43, no. 4 (2012), pp. 804-814.

15 Alex Jeffrey, The Improvised State: Sovereignty, Performance and Agency in Dayton Bosnia (Oxford: Wiley-Blackwell, 2013).

16 Christine Kreamer and Sarah Fee (eds), Objects as Envoys: Cloth, Imagery and Diplomacy in Madagascar (Washington, DC: Smithsonian Institution Press, 2002); Samson Opondo, 'Diplomatic Dissensus: A Report on Humanitarianism, Moral Community and the Space of Death', in Samson Opondo and Michael Shapiro (eds), The New Violent Cartography (London: Routledge, 2012), pp. 95-117. 
state visits begins six months out, and appropriate foods are sourced. ${ }^{17}$ Seating placards are arranged such that the diplomats' bodies might also be arranged. When one Italian ambassador 'found out he had been wrongly placed among the NATO delegation, $[\ldots \mathrm{h}] \mathrm{e}$ stood up, broke his plate in two, and left the building. ${ }^{18}$ Diplomacy, like a dinner plate, is a fragile thing. We must understand diplomatic power as emerging from particular material contexts in which the human and non-human enable one another.

However, the flat ontology of assemblage means that we do not have to stop with the state; rather, the entire diplomatic system can be understood as an assemblage, from which a transnational governmentality emerges. Governmentality is a complex concept that is perhaps best summarized with the pithy description 'the conduct of conduct.' ${ }^{19}$ Most historians see the rise of governmentality and diplomacy as intertwined, in that the diplomatic assemblage shaped modern subjects enrolled in it: 'Foreign countries helped to shape states, since they served for the production of their most important material: servants who were able to convincingly feign complete ignorance and absolute loyalty'. ${ }^{20}$ These new subjects were unique in their specific national loyalties, and yet similar in that they were territorialized to the state.

However, just as elements can participate in multiple assemblages simultaneously, diplomats' loyalties could be multiple: 'Early-modern diplomacy was characterized by both the "plurality" of roles adopted by diplomatic intermediaries and the variety of services they undertook not only for their Princes but also for the other cultural, religious, or social communities to which they belonged'.21 The diplomatic system was therefore composed through states, but not reducible to them. By de-privileging the scale of the state, it becomes possible to see multiple scales emerging simultaneously through the processes of diplomatic assemblage. For example, Stuart Elden traces the simultaneous emergence of both the modern territorial state and of Europe as a

\footnotetext{
17 Iver Neumann, Diplomatic Sites: A Critical Enquiry (New York, NY: Columbia University Press, 2012).

18 Neumann, Diplomatic Sites, p. 63.

19 Tania Murray Li, 'Governmentality', Anthropologica, vol. 49, no. 2 (2007), pp. 275-281.

20 Christian Wieland, 'The Consequences of Early Modern Diplomacy: Entanglement, Discrimination, Mutual Ignorance - and State Building', in Antje Fletcher and Susan Richter (eds), Structures on the Move: Technologies of Governance in Transcultural Encounters (Berlin: Springer Verlag, 2012), p. 271.

21 Noe Cornago, Plural Diplomacies: Normative Predicaments and Functional Imperatives (Leiden: Martinus Nijhoff, 2013), pp. 40-41.
} 
diplomatico-military dispositif [or apparatus ${ }^{22}$ ] through the negotiation of the Treaties of Westphalia:

War is intended to be used judiciously, with a clear sense of why it is being fought, and used strategically to reinforce the balance of power. Diplomacy is to become an instrument or tool, with the negotiations in Westphalia as a model, with a congress of all states involved, and with a system of permanent ambassadors. Europe is seen as a juridico-political entity in itself, with a system of diplomatic and political security; but this is underpinned by the third instrument, each state having a permanent military apparatus of professional soldiers with an infrastructure of fortresses and transport, and sustained tactical reflection. ${ }^{23}$

The idea of states' diplomacy as both a justification for 'internal' governmentality (that is, the maximization of domestic populations and other resources as being necessary for the raison d'état) and as a technique of 'external' projects of governmentality (such as maintaining the balance of power in Europe, or producing a neo-liberal global economy) illustrates the duality that is inherent to diplomacy. Diplomatic practices are of the state and yet also more: they serve as the material tendons of a larger assemblage, one which reshapes the subjectivities of those composing it:

The one-sided diplomat acquires legitimacy from 'inside' a political unit — from the 'national' or the 'communal' — and uses his or her craft to support representations and actions mostly directed to the 'outside' or 'non-national'. The mid-space diplomat acquires legitimacy from the interstitial - from the international or intercommunal - making the most of not taking sides or by functionally distancing oneself from the sides; in other words, uses one's craft to support actions that re-engage and re-position the 'sides'. ${ }^{24}$

Assemblage theory therefore dovetails with the notion of diplomacy as something that is more than the enactment of states' foreign policies. Rather, the

\footnotetext{
22 See Giorgio Agamben, What is an Apparatus? And Other Essays (Stanford, CA: Stanford University Press, 2009).

23 Stuart Elden, 'Governmentality, Calculation, Territory', Environment and Planning D: Society and Space, vol. 25, no. 3 (2007), p. 572.

24 Costas Constantinou, 'Between Statecraft and Humanism: Diplomacy and its Forms of Knowledge', International Studies Review, vol. 15, no. 2 (2013), p. 145.
} 
diplomatic system is a constantly-changing assemblage of diplomats, secure email systems, buildings, state dinners and so on, coming together in ways that continually remake the state, as well as various extra-territorial projects of governmentality. ${ }^{25} \mathrm{New}$ elements of this assemblage can ripple through the system in ways that are unpredictable in advance, reworking political cognition of both individual diplomats and of entire state assemblages. This article traces both the ways in which the intensifying flows of material within the diplomatic system interacted with the physical context of the Foreign Office in unexpected ways, and how the British government subsequently attempted to 'future-proof' the Foreign Office through spatial design that might regulate those flows.

\section{Methods}

Researching life within a secretive organization 150 years ago is challenging. ${ }^{26}$ Without ethnographic or other contemporaneous qualitative methods favoured by researchers in political anthropology and cognate fields, a researcher must turn to the archives, and, as Martin Müller argues, 'documents, no matter how detailed or vivid, always already contain a pre-selection of the association that their authors considered noteworthy'. ${ }^{27}$ For example, ' $[\mathrm{W}] \mathrm{hen}$ the State Papers were compiled at the Public Records Office during the nineteenth century, the correspondence [...] was edited so that things which did not strike the compilers as relevant to what they held to be foreign policy $[. .$. were left out'.28

This occlusion of documents that were not directly related to foreign policy from the FCO archive means that this research is largely based on three Parliamentary Select Committee reports: the 1839 Select Committee on Public

25 Thomas Lemke, 'New Materialisms: Foucault and the "Government of Things"', Theory, Culture, and Society, vol. 32, no. 4, pp. 3-25.

26 Jim Duncan, 'Complicity and Resistance in the Colonial Archive: Some Issues of Method and Theory in Historical Geography', Historical Geography, vol. 27 (1999), pp. 119-128.

27 Martin Müller, 'Opening the Black Box of the Organization: Socio-material Practices of Geopolitical Ordering', Political Geography, vol. 31, no. 6 (2012), p. 383; see also Matthew Kurtz, 'Situating Practices: The Archive and the Filing Cabinet', Historical Geography, vol. 29 (2001), pp. 26-37; and Miles Ogborn, 'Knowledge is Power: Using Archival Research to Interpret State Formation', in Alison Blunt, Pyrs Gruffudd, Jon May, Miles Ogborn and David Pinder (eds), Cultural Geography in Practice (Oxford: Oxford University Press, 2003), pp. 9-22.

28 Neumann, At Home with the Diplomats, p. 44. 
Offices (Downing Street); the 1855 Select Committee on Downing Street Public Offices Extension Bill; and the 1858 Select Committee on Foreign Office Reconstruction, supplemented by diplomatic memoirs and secondary literature. Where Foreign Office records had been tailored to exclude the everyday routines and materialities of the FCO, Parliamentary records were helpful, because in their discussions over the housing of the Foreign Office, the everyday practices and materialities of the Foreign Office intersected with the public purse. Foreign Office staff, architects, engineers and other witnesses to the role of materiality in the Foreign Office spoke before the committees.

It would, of course, be a mistake to take these accounts at face value. First, the imbrications of the human and non-human are often so mundane as to be beneath notice, ${ }^{29}$ some would argue that when the assemblage is 'working', this is even the desired outcome. ${ }^{30}$ Therefore, the accounts brought before the Select Committees were incomplete. Furthermore, the context is highly relevant; this was an opportunity for bureaucratic advancement vis-à-vis other departments. Still, the testimony's depth makes it possible to tease out these weaknesses and to account for them, providing a partial, although meaningful, engagement with the more-than-human diplomacy of the mid-nineteenth century Foreign Office.

This study is not the first to use historical documents in 'New Materialist'oriented research. ${ }^{31}$ Rather than imagining the researcher as occupying a privileged position from which truth can be liberated from the archive, Nick Fox and Pam Alldred imagine research as an assemblage of researcher/documents/interviewees, etc.:

If $[\ldots]$ we see researcher and data (along with many other relations) as a 'research assemblage' [...] with its own affect economy, we begin to recognize research as a territorialization that shapes the knowledge it produces according to the particular flows of affect produced by its methodology and methods. ${ }^{32}$

29 Tim Edensor, 'Illuminated Atmospheres: Anticipating and Reproducing the Flow of Affective Experience in Blackpool', Environment and Planning D: Society \& Space, vol. 30, no. 6 (2012), pp. 1103-1122.

30 Latour, Reassembling the Social

31 Miguel Pina e Cunha, Stewart Clegg and Armenio Rego, 'The Ethical Speaking of Objects: Ethics and the 'Object-ive' world of Khmer Rouge Young Comrades', Journal of Political Power, vol. 7, no. 1 (2014), pp. 35-61.

32 Nick Fox and Pam Alldred, 'New Materialist Social Inquiry: Designs, Methods, and the Research Assemblage', International Journal of Social Research Methodology, vol. 18, no. 4, p. 403 . 
In this formulation, the findings of this research are not so much a subjective truth derived from the archive as they are a line of flight emerging from the encounter between researcher and archive. Indeed, this article conceptualizes the author's findings as emergent from the 'research assemblage'. The archive itself is a sedimentation of histories, curated to produce a monument to the past as possessing certain properties. The archive is, of course, from the past, but requires work by others over time to maintain its order. The reports' intersection with the author's theoretical agenda opened up a latent capacity within what would otherwise be an ordinary copy of Hansard (the official record of Parliament). This process of assemblage could easily have been otherwise, had the reports been classified differently or had the author left early for lunch and not discovered them. In short, the becoming of this research itself has a 'micro-history', ${ }^{33}$ much like the people and buildings that it examines, complete with un-actualized lines of flight and capacities yet undiscovered.

\section{Disassembling and Reassembling the Foreign Office}

A brief overview of events is warranted, given the period of time (roughly 35 years) over which these select committees met and construction occurred. From 1793 onwards, the Foreign Office was based in five houses: 16-18 Downing Street (number 15 was later added) and two houses behind those on Fludyer Street (a street now disappeared, but previously south of Downing Street). These houses were combined through the demolition of internal walls, and a new entrance was created by Sir John Soane. ${ }^{34}$ The rise of Lord Palmerston, first as foreign secretary (1830-1834, 1835-1841 and 1846-1851) and then as prime minister (1855-1858 and 1859-1865), boded well for the Foreign Office's desire to move out of its run-down, ad-hoc offices. In 1836 the architect Decimus Burton was commissioned to design new facilities in Downing Street. The first select committee met in 1839 to consider his plans. Despite widespread agreement on the need to build, no decision was made because of an unexpected event - the need to rebuild the Houses of Parliament (which had been destroyed by fire in 1834).

Still, the Foreign Office's material deterioration only got worse, and William Molesworth, the First Commissioner of Works, called for another set of plans to be drawn up, having rejected Burton's plan as encroaching on St James's

33 Simon Naylor, 'Historical Geography: Geographies and Historiographies', Progress in Human Geography, vol. 32, no. 2 (2008), p. 266.

Edward Hertslet, Recollections of the Old Foreign Office (London: John Murray, 1901). 
Park. James Pennethorne, the government's official architect, drew up plans for a new Foreign Office and presented them to the second select committee in 1855 . Despite another endorsement by the new committee, Pennethorne's plans languished as well, this time a result of the Crimean War. The Crimean War did more than just consume valuable funds; it also highlighted 'the drawbacks of having a war directed from so many different buildings in London; rationalization became a popular cry, with a unified War Office becoming a major justification for a new government building. ${ }^{35}$ The diplomaticomilitary dispositif demanded efficiency within the state in order to contribute to governmentality above the state.

By 1855, Palmerston was in 10 Downing Street, looking across the street at the dilapidated Foreign Office. He decided on open architectural competitions to design a new Foreign Office and War Office, with a third category of competition for the overall design of Whitehall itself. Palmerston's vague instructions inspired 218 entries, but produced contradictory winners, with the design of each winner clashing with the other, and both clashing with the winner of the comprehensive Whitehall design. To settle this, the third select committee was formed. In the end, George Gilbert Scott was selected to create a palace of administration, given that he had scored highly in all three categories. Subsequently, the War Department was located elsewhere, and the Foreign Office shared the new building with the India Office. In November 1861, the old Foreign Office in Downing Street was demolished to make way for the new building (or buildings, as the two parts of the palace remained distinct), and after finding interim quarters in Pembroke House, the Foreign Office moved into its new facilities in June 1868. Scott later added two new quadrants to the new palace of administration, housing the Home and Colonial Offices (see Fig. 1).

Just as the Crimean War had led to a reorganization of the entire British government (albeit over a span of twenty years), the First World War shocked the apparatus of British government. The requirements of the diplomatic apparatus grew in proportion to the complexity of foreign affairs. After the Second World War, the India Office was dissolved because of decolonization, and the Commonwealth Relations Office (originally the Dominions Office) absorbed the Colonial Office and was itself eventually absorbed into the Foreign Office in 1968. In 1978, the Home Office decamped to Queen Anne's Gate and the Foreign and Commonwealth Office was left in sole possession of Scott's palace of administration. 


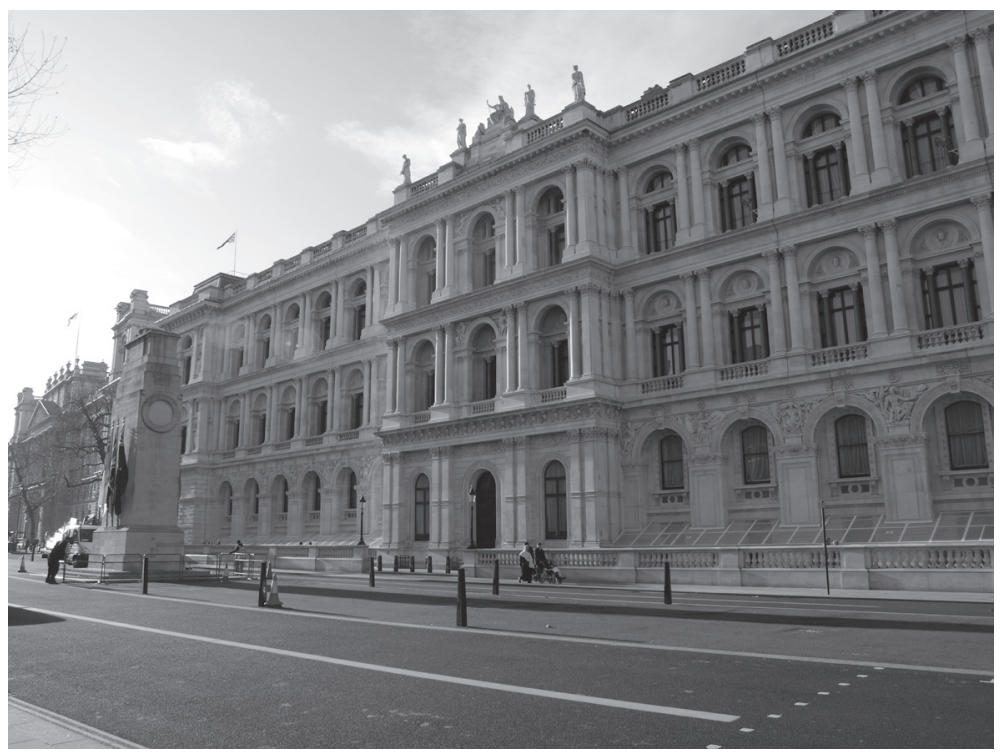

FIGURE 1 The completed 'palace of administration'.

CUCL CREATIVE MEDIA SERVICES

\section{Revenge of/on the Paper Pushers: Paper-Power and Diplomacy}

This narrative is a traditional, human-centric narrative of bureaucracy, government and international affairs. In what follows, the article will demonstrate the first conceptual point - on the importance of the non-human to diplomacy - by de-emphasizing human agency in favour of a relational notion of co-agency, in which not only is human agency enabled through relations with materials, but those materials exert themselves on the people with whom they work. This is accomplished by re-centring the narrative of the Foreign Office on paper. ${ }^{36}$

The history of writing as part of post-human political regimes has been traced from ancient times through the colonial era and into the present, and is inextricably linked with diplomacy. ${ }^{37}$ 'Etymologically, [...] the word is derived from the ancient Greek word diploun (to double), and from the Greek noun

36 See also Jonathan Darling, 'Another Letter from the Home Office: Reading the Material Politics of Asylum', Environment and Planning D: Society and Space, vol. 32, no. 3 (2014), pp. 484-50o; and Florian Weisser, 'Practices, Politics, Performativities: Documents in the International Negotiations on Climate Change', Political Geography, no. 40 (early online). Paul Adams, 'Networks of Early Writing', Historical Geography, vol. 38 (2010), pp. 70-89; Ogborn, 'Knowledge is Power'; and Weisser 'Practices, Politics, Performativities'. 
diploma, which refers to an official document written on double leaves (diploo) joined together and folded (diplono). ${ }^{38}$ When the Foreign Office was founded, paper had long replaced leaves as the surface of inscription for diplomacy. Paper's advantages were manifest. The nineteenth century saw innovations in paper manufacturing, enabling cheap wood-based paper to flood the market. ${ }^{39}$ This, along with printing press innovations and steam-powered transportation, enabled a wider circulation of paper and consequently an intensification of governmental reach in distant corners of the globe. ${ }^{40}$ Indeed, the importance of paper to the Foreign Office was first stated to the select committees by James Bandinel in 1839, who argued that access to twenty years' worth of paper was necessary for the daily running of the Foreign Office. ${ }^{41}$

However, technological change alone is not enough to explain the changes occurring to the Foreign Office at the start of the earlier narrative. Indeed, the rise of paper can be traced across all bureaucracies. Rather, what is special here is that changes occurring in the diplomatic system resonated with the Office's requirement for paper; the early 1800 s saw independence for most of Central and South America and therefore a proliferation of geopolitical subjects. Foreign Office employee Joseph Planta described the intensity with which the office's work had increased:

When I first knew the office there were not above three or four foreign ministers accredited to this country; the number has now increased at least to four or five times that amount. Likewise, our relations with foreign countries were by no means as considerable as they are now; and latterly, in Mr Canning's time, the whole of South America was thrown open too, which almost doubled the business of the foreign office. ${ }^{42}$

This posed challenges with regard to the number of staff to be housed, but more crucially the volume of paper and the way in which it interacted with other elements of the Foreign Office assemblage.

38 Costas Constantinou, On the Way to Diplomacy (Minneapolis, MN: University of Minnesota Press, 1996), p. 77 .

39 Peter Burger, Charles Fenerty and his Paper Invention (Toronto, on: Peter Burger, 2007).

40 For an account of the seventeenth and eighteenth century impact of paper and innovations in transportation, see Miles Ogborn, Indian Ink: Script and Print in the Making of the English East India Company (Chicago, IL: University of Chicago Press, 2007).

41 Report from Select Committee on Public Offices (Downing Street) with the Minutes of Evidence, Appendix, and Plans (1839).

42 Report from Select Committee on Public Offices (Downing Street) with the Minutes of Evidence, Appendix, and Plans, p. 28. 
The select committees all traced the need to build new facilities, rather than shore up the Downing Street offices, to this increased circulation of paper within the diplomatico-military dispositif. The 1858 select committee received evidence of a near-exponential increase in communications coming through the Foreign Office - all pre-dating the inclusion of the telegraph in the Foreign Office's links to overseas diplomats (see Table 1 below). This, combined with the need for on-site storage, meant that the paper to be stored in the Foreign Office expanded radically year on year. This trend was exacerbated by Permanent Under-Secretary Edmund Hammond's claim in $185^{8}$ that the office then needed 30 to 50 years' worth of papers on site ${ }^{43}$ - although this might, of course, have simply been a gambit to obtain more space. Lewis Hertslet, the librarian and keeper of the papers in the Foreign Office for 38 years, had this exchange with the chair of the 1839 committee:

Chair: What is the extent of the library you have charge of?

Hertslet: The library consists of about 5,000 volumes, and the number of volumes of manuscripts now in the office is between 4 , and 5,000 .

Chair: How are they placed?

Hertslet: They are placed in the most irregular and inconvenient manner possible; some of them are stowed away in obscure rooms and passages, and there is no semblance of a library.

Chair: Are they all on the same floor?

Hertslet: No; they are on two floors, or rather on three floors, and these are distributed in the four or five houses of which the Foreign Office consists. ${ }^{44}$

Hertslet's son, who later worked in the Foreign Office, describes the bookshelves as being 'three-deep', complicating any effort at finding a particular book. ${ }^{45}$ If we mention here that the Foreign Office was at this time in no way fireproofed, some sense of the tenuous circumstances is achieved.

43 Report from the Select Committee on Foreign Office Reconstruction; Together with the Proceedings of the Committee, Minutes of Evidence, Appendix, and Index (1858).

44 Report from Select Committee on Public Offices (Downing Street) with the Minutes of Evidence, Appendix, and Plans, p. 14.

45 Hertslet, Recollections of the Old Foreign Office. 
TABLE 1 The increase in despatches received at and sent from the Foreign Office, 1821-1857

\begin{tabular}{|c|c|c|c|c|c|c|c|c|c|}
\hline \multirow[b]{2}{*}{ year } & \multicolumn{2}{|c|}{$\begin{array}{c}\text { Political } \\
\text { Department }\end{array}$} & \multicolumn{2}{|c|}{$\begin{array}{c}\text { Consular } \\
\text { Department }\end{array}$} & \multicolumn{2}{|c|}{$\begin{array}{l}\text { Slave Trade } \\
\text { Department }\end{array}$} & \multicolumn{2}{|c|}{ TOTAL } & \multirow{2}{*}{$\begin{array}{l}\text { Grand } \\
\text { Total, } \\
\text { Received } \\
\text { and Sent }\end{array}$} \\
\hline & Received & Sent & Received & Sent & Received & Sent & Received & Sent & \\
\hline 1821 & 4,379 & 1,630 & - & - & 155 & 29 & 4,534 & 1,659 & 6,193 \\
\hline 1822 & 3,929 & 1,390 & - & - & 175 & 116 & 4,104 & 1,506 & 5,610 \\
\hline 1823 & 4,893 & 1,909 & - & - & 101 & 80 & 4,994 & 1,989 & 6,983 \\
\hline 1824 & 5,902 & 2,747 & - & - & 391 & 246 & 6,293 & 2,993 & 9,286 \\
\hline 1825 & 5,635 & 2,740 & - & - & 390 & 294 & 6,025 & 3,034 & 9,059 \\
\hline 1826 & 5,635 & 2,522 & 2,477 & 973 & 474 & 321 & 8,586 & 3,816 & 12,402 \\
\hline 1827 & 4,135 & 2,002 & $2,45^{6}$ & 966 & 427 & 275 & 7,018 & 3,243 & 10,261 \\
\hline 1828 & 4,908 & 2,471 & 2,644 & 1,167 & 382 & 259 & 7,934 & 3,897 & 11,831 \\
\hline 1829 & $4,5^{6} 5$ & 2,033 & 2,274 & 874 & $45^{1}$ & $5^{6} 3$ & 7,290 & 3,470 & 10,760 \\
\hline 1830 & 4,926 & 2,426 & 2,421 & 929 & 494 & $35^{\circ}$ & 7,841 & 3,705 & 11,546 \\
\hline 1831 & 5,889 & 2,510 & 2,949 & $1,5^{13}$ & 409 & 307 & 9,247 & 4,330 & 13,577 \\
\hline 1832 & 5,279 & 3,009 & 2,988 & 1,644 & 299 & 197 & 8,566 & $4,85^{\circ}$ & 13,416 \\
\hline 1833 & 5,529 & 2,815 & 2,536 & 1,689 & 313 & 260 & 8,378 & 4,764 & 13,142 \\
\hline 1834 & $5,75^{1}$ & 3,487 & 2,624 & 1,605 & 427 & 395 & 8,802 & 5,487 & 14,289 \\
\hline 1835 & 5,487 & 2,928 & 2,954 & 1,664 & 595 & 474 & 9,036 & 5,066 & 14,102 \\
\hline 1836 & 6,904 & 4,268 & 3,226 & 2,055 & 693 & 472 & 10,823 & 6,795 & 17,618 \\
\hline 1837 & 6,881 & 4,503 & 3,449 & 1,942 & 745 & 403 & 11,075 & 6,848 & 17,923 \\
\hline 1838 & 7,511 & 5,163 & 3,213 & 1,584 & 848 & 687 & 11,572 & 7,434 & 19,006 \\
\hline 1839 & 7,892 & 5,535 & 3,234 & 1,796 & 1,128 & 1,056 & 12,254 & 8,387 & 20,641 \\
\hline 1840 & 8,426 & 6,032 & 3,324 & 2,001 & 1,257 & 946 & 13,007 & 8,979 & 21,986 \\
\hline 1841 & 8,922 & 5,574 & 4,484 & 1,813 & 1,740 & 1,514 & 15,146 & 8,901 & 24,047 \\
\hline 1842 & 8,192 & 4,533 & 5,461 & 1,882 & 1,911 & 1,781 & 15,564 & 8,196 & 23,760 \\
\hline 1843 & 8,363 & 4,597 & 5,309 & 1,784 & 1,854 & 1,910 & $15,5^{26}$ & 8,291 & 23,817 \\
\hline 1844 & 8,615 & 5,032 & 5,279 & 2,136 & 1,926 & $1,55^{8}$ & 15,820 & 8,726 & 24,546 \\
\hline 1845 & 7,989 & 4,280 & 5,353 & 2,310 & 2,169 & 2,029 & 15,511 & 8,619 & 24,130 \\
\hline 1846 & $8,95^{1}$ & 5,442 & 5,112 & 2,257 & 1,604 & 1,619 & 15,667 & 9,318 & 24,985 \\
\hline 1847 & 10,755 & 7,483 & 5,215 & 2,415 & 1,461 & 1,537 & 17,431 & 11,435 & 28,866 \\
\hline 1848 & $10,5^{6} 5$ & 7,772 & 5,323 & 3,030 & 1,327 & 1,323 & 17,215 & 12,125 & 29,340 \\
\hline 1849 & 11,705 & 7,660 & 5,800 & 3,081 & 1,379 & 1,100 & 18,884 & 11,841 & 30,725 \\
\hline $185^{\circ}$ & $11,35^{8}$ & 8,892 & 5,638 & 3,071 & 1,506 & 1,175 & 18,502 & 13,138 & 31,640 \\
\hline $185^{1}$ & $11,5^{11}$ & 8,705 & 6,186 & 3,914 & 1,678 & 1,320 & 19,375 & 13,939 & 33,314 \\
\hline $185^{2}$ & 11,902 & 7,835 & 6,292 & 3,734 & $1,25^{2}$ & 1,028 & 19,446 & 12,597 & 32,043 \\
\hline
\end{tabular}


TABLE 1 The increase in despatches received at and sent from the Foreign Office (cont.)

\begin{tabular}{|c|c|c|c|c|c|c|c|c|c|}
\hline \multirow[b]{2}{*}{ year } & \multicolumn{2}{|c|}{$\begin{array}{c}\text { Political } \\
\text { Department }\end{array}$} & \multicolumn{2}{|c|}{$\begin{array}{c}\text { Consular } \\
\text { Department }\end{array}$} & \multicolumn{2}{|c|}{$\begin{array}{l}\text { Slave Trade } \\
\text { Department }\end{array}$} & \multicolumn{2}{|c|}{ TOTAL } & \multirow{2}{*}{$\begin{array}{l}\text { Grand } \\
\text { Total, } \\
\text { Received } \\
\text { and Sent }\end{array}$} \\
\hline & Received & Sent & Received & Sent & Received & Sent & Received & Sent & \\
\hline 1853 & 13,143 & 9,120 & $6,5^{6} 5$ & 3,826 & 1,344 & 1,115 & 21,052 & 14,061 & 35,113 \\
\hline 1854 & 17,969 & 15,661 & 7,436 & $5,5^{62}$ & 1,269 & 953 & 26,674 & 22,176 & $48,85^{\circ}$ \\
\hline 1855 & 18,855 & 17,246 & 9,543 & 9,571 & 1,166 & 938 & 29,564 & 27,755 & 57,319 \\
\hline 1856 & 19,719 & 17,340 & 10,427 & 7,606 & $1,55^{6}$ & 1,266 & 31,702 & 26,212 & 57,914 \\
\hline 1857 & 20,268 & 19,057 & 9,979 & 7,313 & 1,599 & 1,307 & 31,846 & 27,677 & $59,5^{23}$ \\
\hline
\end{tabular}

Paper is here a bulky, combustible problem, but it would be a mistake to consider paper in isolation, a mere by-product of the diplomatic system. 'The political significance of materials is not a given; rather, it is a relational, a practical and a contingent achievement. ${ }^{46}$ In the specific case of the old Foreign Office, it was the relations formed among a range of materialities, including paper, that posed a particular problem. First, the old Foreign Office was composed of buildings that had been built on alluvial soil, as the Surveyor of Works and Buildings, Henry Seward, told the 1839 committee:

I know there was formerly a ditch running along very near the centre of that mass of buildings, taking the old front of Sir Samuel Fludyer's house, and, running between the houses in Downing Street and Fludyer Street; it was an ancient sewer, therefore the ground on each side of it is bad. ${ }^{47}$

Indeed, when the neighbouring houses were taken down because of subsidence, it revealed how dependent the Foreign Office had been on them for support (see Fig. 2).

Second, the paper was entering into assemblage with houses built for private use, and so their construction was not intended for such weight. Paper individually is light, but the ability to pack a great deal of it in a relatively small

46 Andrew Barry, Material Politics: Disputes along the Pipeline (Chichester: Wiley, 2013), p. 183 .

47 Report from Select Committee on Public Offices (Downing Street) with the Minutes of Evidence, Appendix, and Plans), pp. 1-2. 


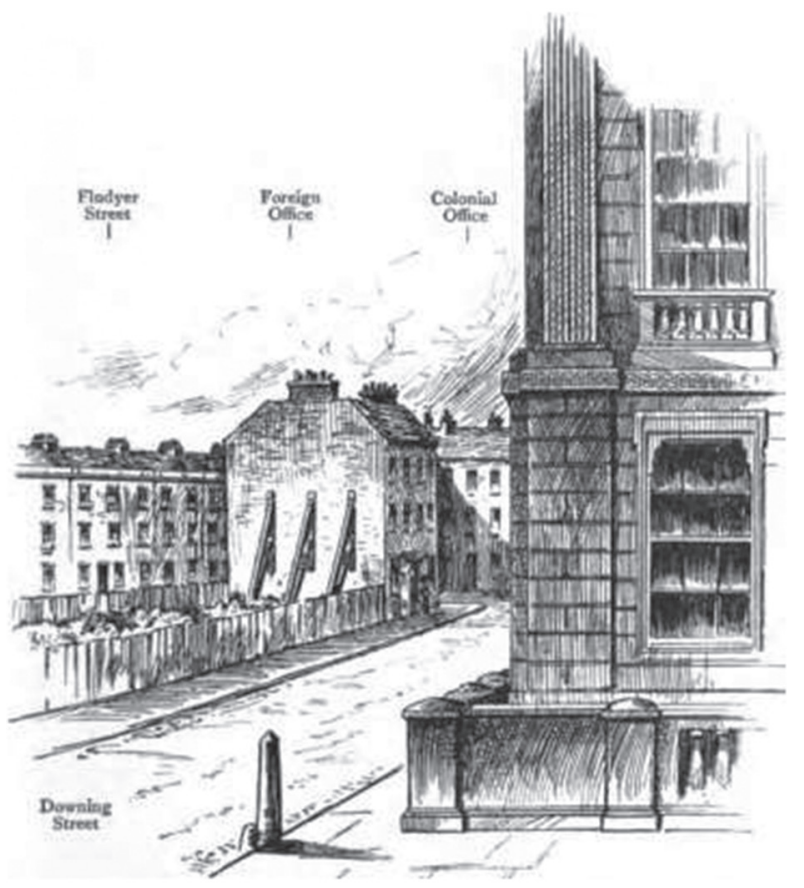

FIGURE 2 The Downing Street Foreign Office being held up by struts. ${ }^{49}$

space causes its weight to accumulate. Thomas Chawner, an architect in the Land Revenue, reported to the 1839 committee that papers had been stored in the upper stories of the houses, which only made the structure more unstable. ${ }^{48}$ Much of the paper was thus moved to the first floor, but this put the clerks up high, which made for inefficiency as they frequently ran in and out of the building. As paper proliferated into every room, posts were installed in the middle of rooms to support the ceiling above. This situation was further complicated by the removal of interior walls to create larger work spaces and the creation of openings in walls to facilitate movement within the adjoined houses. Seward spoke to his concerns about the former house of Sir Samuel Fludyer:49

[T] here has been an alarm about this house in consequence of the alterations made with a view to meeting particular calls for accommodation, laying the rooms together, and taking away walls; and it likewise appears

\footnotetext{
48 Report from Select Committee on Public Offices (Downing Street) with the Minutes of Evidence, Appendix, and Plans).

49 Hertslet, Recollections of the Old Foreign Office.
} 
that the bow front to the west is considerablycrushed in the lower part, in consequence of the heavy weights which have been thrown upon it. ${ }^{50}$

There is one more relevant element in the assemblage, and again it is one that is particular to the Foreign Office: the printing presses. Just as the paper had been held in the higher stories until this hazard was recognized, the printing presses had likewise been stored aloft. These printing presses were constantly at work, as the Foreign Office not only had its own confidential printing to do, but also confidential printing for the entire government. Consequently, at the top of these poorly founded, internally unsound and over-freighted houses were large, heavy and constantly vibrating machines, and as Thomas Chawner testified in 1839: '[A]t the time I was there, I found a great quantity of types used in printing; these they moved from one place to another, which I consider improper; if great weights are shifted from one place to another, it is likely to cause settlements. 51

By the time the 1855 select committee met, the printing presses had been moved into the basement. Still, the building retained a materialized memory of its previous excesses. Party walls sank into the earth, floors varied by as much as a foot across a room, and doors had to be re-hung in order to enable them to open. The engineers worked very hard to keep the building from falling down. Collectively, then, it can be said that the paper/print assemblage, the soil substratum and the houses themselves were brought into relation through the daily work of the Foreign Office, leading to a set of resonances that rippled through the physical structure, leading to safety fears and obvious inefficiencies in public work. Lord Malmesbury, Foreign Secretary in $185^{2}$ and 1858-1859, 'was made perfectly aware of the physical state of his new department in the most tangible way when part of the ceiling of his room fell onto his desk.'52 Another time, a wall adjoining a fireplace crumbled unexpectedly and the fire splashed out into the Reference Room, which held innumerable quantities of paper. A large fire was only narrowly averted, one that might have destroyed the diplomatic archive. In short, paper was not just the archive enabling British contributions to the larger diplomatico-military dispositif; it had a material form that acted back on the apparatus.

50 Report from Select Committee on Public Offices (Downing Street) with the Minutes of Evidence, Appendix, and Plans), p. 3.

51 Report from Select Committee on Public Offices (Downing Street) with the Minutes of Evidence, Appendix, and Plans), pp. 5-6. 


\section{Governing Affective Atmospheres: Bodies, Air and Light}

This section demonstrates the second conceptual point by emphasizing the ways in which the government attempted to 'future-proof' the new Foreign Office building through practices of spatial design that sought to govern material circulations.

The process of designing a new Foreign Office became centred on the governance of affective atmospheres. These atmospheres emerge in part through architectural design, which 'enables the channelling of affects through configurations of fields that architects and buildings intend to, and sometimes do, create. ${ }^{33}$ The 1858 select committee met to adjudicate among the various winners of Palmerston's architectural competition, with reference to the needs of the Foreign Office. On the one hand, the myth of the Foreign Office as a black box that is distinct from other branches of government was clearly asserted in claims by the Permanent Under-Secretary regarding the necessity of a highly territorialized Foreign Office with regard to human bodies: the circulation of bodies within the Foreign Office ought to be enabled as much as possible, while bodies outside the Foreign Office ought to remain so. This required a coding of bodies as acceptable or unacceptable. However, this stark territorialization belies the perceived need for other elements, such as light and air, to be able to enter and permeate the atmosphere of the Foreign Office. As Foucault argues in his lecture on apparatuses, 'it was a matter of organizing circulation, eliminating its dangerous elements, making a division between good and bad circulation, and maximising the good circulation by diminishing the bad. ${ }^{54}$

The circulation of bodies is not entirely separate from the issue of paper raised earlier. Indeed, the solution offered to the Foreign Office for its paper problem was to submit all of its papers, rather than just those beyond the twenty year rule, to the State Paper Office, where all the Privy Council's and Secretaries of State's archives were stored (the Office had been built in 1833 on Duke Street just outside St James's Park, near the Foreign Office). However, this was roundly refused by all those who testified in 1839 . For instance,

Chair: Have you occasion to refer often to the papers of a distant date?

Hertslet: I cannot say that we have; but we should more often refer to them if they were easier of access [i.e., not in the State Paper Office]; for it not infrequently happens that references are 
required at a late hour of the day - for instance, Parliamentary references - that must be reported upon forthwith; there is then no time to send to the State Paper Office; and if there were, the State Paper Office was probably shut, even before the question arose; and we are compelled to do the best we can with imperfect materials. ${ }^{55}$

Here, the territorialization of the Foreign Office is coded through the temporality of its work; the despatches arrive late, and the State Paper Office was only open from nam until $4 \mathrm{pm}$.

This territorialization becomes clearer when the debate turns to the circulation of bodies. An explicit aim of Permanent Under-Secretary Hammond was maintaining a boundary between the inside and outside of the Office. When discussing the possible shape of the palace of administration, Hammond had the following exchange with the committee:

Chair: $\quad$ You would have your office self-contained?

Hammond: Certainly. Our office is quite large enough for any one set of servants to manage; and especially as regards office hours; our system in the office is so thoroughly different from that of every other office, as far as I am acquainted with other offices, that we never could combine our arrangements with those of another office.

Chair: Then you would not like even a door into the Colonial or any other office?

Hammond: No. I should, in the first place, particularly dislike the facility of communication between the clerks of different offices, from the circumstance, among other reasons, that our real business hours, that is hours of pressure, commence when other offices are rising, and it is a very natural thing for acquaintances from one office to come into the other office just at what would be to us the most inconvenient time. In fact, I would much rather have as few visitors in the office, and as little encouragement to visitors, as there could possibly be..$^{56}$

55 Report from Select Committee on Public Offices (Downing Street) with the Minutes of Evidence, Appendix, and Plans), p. 14.

$5^{6}$ Report from the Select Committee on Foreign Office Reconstruction; Together with the Proceedings of the Committee, Minutes of Evidence, Appendix, and Index, p. 5. 
This policing of the Foreign Office notably foreshadows later concerns over secrecy and the imposition of a strict visual regime within the diplomaticomilitary dispositif, ${ }^{57}$ but does so with a concern for atmospheres of efficiency, which in turn can create the conditions for a more effective governmentality.

If Hammond had a strong desire to police the boundaries of the Foreign Office to produce an atmosphere of efficiency, he also wanted an internal space that facilitated movement. The old Foreign Office was notable for its clutter and poor organization. Hertslet describes, for example, that the librarian's office was on the first floor, while the Reference Room was on the ground floor in a different part of the building. Hammond testified on the convoluted layout of the office in 1858 :

The divisions are scattered all over the office; three of my political divisions out of four are in the second storey; and if I want to speak to one of the clerks, I must either bring him down to me, or if I want myself to refer to a paper or the register in the department, I must go up myself.58

Hammond saw the new building as an opportunity to aid the circulation of bodies within the building via the production of an idealized hierarchical space of communication:

All our clerks should be together; that is to say, every division should be complete in itself. The senior clerk should have one room for himself and one or two other clerks, and the juniors should be in a room going out of it, and those rooms should be as much as possible in direct communication with the Under-Secretary of State immediately superintending the division to which that senior clerk belongs. ${ }^{59}$

Hammond's ideal office is a sprawling horizontal space. Later, when he is asked to testify about the number of floors he desires, he struggles to articulate what he would put on the two floors not described in the above quote. He grudgingly puts the slave trade department and the passport office in the basement and the translator and treaty department in the attic; the political staff ought to all

57 See Fraser MacDonald, 'Geopolitics and "the Vision Thing": Regarding Britain and America's First Nuclear Missile', Transactions of the Institute of British Geographers, vol. 31, no. 1 (2006), pp. 53-71.

$5^{8}$ Report from the Select Committee on Foreign Office Reconstruction; Together with the Proceedings of the Committee, Minutes of Evidence, Appendix, and Index, p. 2.

59 Report from the Select Committee on Foreign Office Reconstruction; Together with the Proceedings of the Committee, Minutes of Evidence, Appendix, and Index, p. 4. 
be located on the same floor, and thus be easily accessible. His mental hierarchy of Foreign Office core functions is transmuted into his idealized space.

The committee also became wrapped up in what has been referred to elsewhere as a knowledge controversy, or a decision to be made 'in the face of persisting disagreement between experts about what the problems are, and how they should be addressed' ${ }^{\prime 0}$ At issue was how to guarantee the presence of light and fresh air throughout the new building to produce an affective atmosphere of efficiency ${ }^{61}$ Hammond makes this clear to the committee ('The great object in a public office, as far as the interior is concerned, is to have as much external air and as much external light as possible') ${ }^{62}$ and the committee tacitly accepts it as true. This is interesting, as Hammond is specifying that public offices have greater requirements for this than private residences. While his argument is couched generally with regard to public offices, it is nevertheless rooted in the specific experience of the Foreign Office: the old Foreign Office was materially failing because it had been designed to serve as private houses. In this case and in the above (governing bodies), an efficient atmosphere is the desired effect of spatial design.

Hammond stated both his desire for large, open windows to allow in light and fresh air, as well as an aversion to courtyards, which he said amplified the sound of carriages turning around and also prevented truly fresh air from entering. While every architect disputed his claim about courtyards, a particularly divisive knowledge controversy erupted over whether a Gothic or Italianate style was better for the circulation of light and air. Both Henry Coe and Charles Barry, winners of the first and second prizes for the Foreign Office design (respectively), used Italianate design, and argued that Gothic mullions (vertical elements in a window separating panes of glass) limited the light and air entering the building. Barry couched his aversion to the Gothic style for public buildings as more than just his opinion, but as 'the frequently expressed opinion of gentlemen with whom I have necessarily come into contact in this very building in which we sit [Parliament], when I was acting for my father [Sir Charles Barry, architect of the Gothic Houses of Parliament]. ${ }^{63}$

6o Barry, Material Politics, p. 8.

61 See Felix Driver, 'Moral Geographies and the Urban Environment in Mid-nineteenth Century England, Transactions of the Institute of British Geographers, vol. 13, no. 3 (1988), pp. $275-287$.

62 Report from the Select Committee on Foreign Office Reconstruction; Together with the Proceedings of the Committee, Minutes of Evidence, Appendix, and Index, p. 4.

63 Report from the Select Committee on Foreign Office Reconstruction; Together with the Proceedings of the Committee, Minutes of Evidence, Appendix, and Index, p. $5^{8 .}$ 
George Gilbert Scott, the third prize winner (and eventual architect), staunchly defended the Gothic style (he would, after winning, be forced by Palmerston to switch to Italianate). His argument was that windows could be widened to allow for mullions and still admit light and air. Indeed, he presented statistics on window size for various buildings around London to illustrate the unfounded prejudice against the Gothic style. He further argued that: 'As to the windows, the capability of window light in the Gothic considerably exceeds the capability in Italian architecture. I may mention that if it had not been so, it would have involved a great absurdity in the conduct of our forefathers here, and their contemporary architects in Italy' 64

Scott detailed technological inventions that enabled Gothic windows to ventilate just as well as Italian ones. He then sealed his argument with a patriotic reference to the indigenous nature of the Gothic vis-à-vis the Italian style. In doing so, he effectively coded the material elements of the Foreign Office apparatus with nationalism, a coding that resonates because of the specific functions accorded to the Foreign Office building.

The final report from the select committee specifically set aside the issue of style. The committee decided that the style did not significantly impact upon the price of the building, the presence of light and air, or even neighbourhood coherence (as the site was between the Gothic Houses of Parliament and the Italianate Horse Guards Parade). This knowledge controversy, contested as it was by the leading architects in the land, was ultimately decided to be irrelevant to the state's interest in the affective atmospheres fostered in the new Foreign Office.

\section{Conclusions}

The fall and rise of the material infrastructure of the Foreign Office could be understood as a banal story of engineering, architecture and the public sector. However, this article shows how the historical record indicates the role of the non-human in the world of diplomacy. The slow-motion collapse of the old Foreign Office resulted from resonating materialities (soil, paper and printing press) intersecting over a range of temporalities (the vestigial engineering of sewers and private houses, the proliferation of states and the acceleration of diplomatic communication). Furthermore, the Foreign Office adopted a new configuration with the influx of finance and expertise that was offered by

64 Report from the Select Committee on Foreign Office Reconstruction; Together with the Proceedings of the Committee, Minutes of Evidence, Appendix, and Index, p. 65. 
central government, reterritorializing the Office as a foreign policy actor distinct from other parts of the British 'external' project of governmentality, such as the Colonial Office and the War Office (even sharing books was deemed impossible). This event was an opportunity to 'mineralize' resources into a form that maximized governmental efficiency and 'future-proofed' the Foreign Office through practices of spatial design. This provoked knowledge controversies, around which material forms enabled the right circulations and prevented the wrong ones, with Parliamentary debate hinging on baroque technologies such as window sashes. The fact that no decision was made between Gothic and Italianate is less important than that the introduction of light and air to generate atmospheres of governmental efficiency was universally deemed crucial.

This story has implications for how scholars consider both governmentality and diplomacy. First, scholars of governmentality have often focused on archives as a key instrument of state power. Typically the archive is considered in an abstract, dematerialized way, and as such it is difficult to discern its agency. However, in this case the weight and mode of reproducing the archive came to matter greatly. The archive's materiality was demonstrated as being capable of affecting both the state apparatus in which the archive was sustained and the wider dispositif of the geopolitical order in ways that were both unpredictable and specific. In this case, the additional space that was provided for paper in the new building was still not enough, and was also productive of new lines of flight. For instance, the recent revelation of one million unacknowledged files from the colonial era in a secret illegal archive in Hanslope Park indicates that the proliferation of paper in the Foreign Office reached epic proportions even after the Foreign and Commonwealth Office took over George Gilbert Scott's entire creation. ${ }^{65}$ The fifteen miles of floor-to-ceiling bookshelves could not have been accommodated in any of the architects' proposals. Yet the enlarged Foreign Office, with the reduction of paper in a digitizing workplace, enabled the bureaucracy to expand materially in other ways, most notably in terms of staff (currently roughly 4,500 civil servants). The shift to digital archives - as part of the FCO's 'Digital Transformation' - offers a new material milieu in need of investigation.

65 Ian Cobain, 'Foreign Office Hoarding $1 m$ Historic Files in Secret Archive', The Guardian (18 October 2013), available online at http://www.theguardian.com/politics/2013/oct/18/ foreign-office-historic-files-secret-archive (last accessed 2 April 2015). 
For diplomatic studies, a consideration of diplomatic practices as contributing to international society is not new. ${ }^{66}$ Indeed, Costas Constantinou's reminder that diplomats can serve as a connective tissue - a mid-space reflects a profoundly humanistic vision of what the profession of diplomacy can be. ${ }^{67}$ In focusing on people to the exclusion of things, materials and their relations, such a vision can eliminate from view the paper, wires, cables, gifts, and so on, that serve as the material infrastructure of diplomacy. More-thanhuman diplomatic studies could highlight these elements. Some might see this as watering down the responsibility of diplomats to produce solutions. Rather, it is a recognition that human intentions are not enough to produce political change; instead, diplomats must become attuned to the dynamics of the diplomatic system and discern where and when their efforts are likely to make a difference. Connolly refers to those with this skill as seers:

[A] seer does not only express premonitions about an uncertain future at protean moments. Those same skills and sensitivities are also indispensable to the formation of new maxims, judgments, concepts, and strategies at untimely moments when a collection of old precepts, habits, and standards of judgment are insufficient to an emerging situation. ${ }^{68}$

A more-than-human diplomacy is therefore not one that abdicates responsibility; rather, it is one that recognizes the dynamic flow of power within assemblages and sees its responsibility as finding the 'maxims, judgments, concepts, and strategies' that are appropriate for humanity's emerging problems.

This research also illustrates a problem for scholars of assemblage. Theorists of assemblage have at times struggled to articulate power relations within specific assemblages, because of the fundamentally open-ended and relational ontology of assemblage. The emergent agency of the diplomatico-military dispositif can be seen acting on the Foreign Office's bodies and buildings through the increasingly intense influx of paper and its complex relations with the old Foreign Office. However, the new building's immense capacity to hold paper enables it today to be filled with bodies, producing new capabilities in the specialist, networked diplomacy that the FCO is pioneering today. This calls into question the temporalities of power: to identify power at any moment is also to identify a particular duration for that power. However, the

66 Hedley Bull, The Anarchical Society: A Study of Order in World Politics (New York, NY: Columbia University Press, 2002).

67 Constantinou, 'Between Statecraft and Humanism'.

68 William Connolly, A World of Becoming (Durham, NC: Duke University Press, 2011), p. 164. 
open-ended spatialities of assemblage are also open-ended temporalities. The desire of scholars to identify powerful elements narrows the temporalities of that assemblage in ways that limit our sense of assemblage theory's potential. Future research should remain open to a range of political temporalities in order to imagine a more-than-human politics.

Jason Dittmer is Professor of Political Geography in the Department of Geography at University College London. His research expertise is in popular geopolitics, especially the intersection of media and everyday life. His most recent project is a reconsideration of diplomacy through the lens of assemblage theory, looking at the material connections between foreign policy apparatuses and how they work in an everyday sense. 